\title{
Evaluation of Herbicides for the Control of Annual Grass Weeds in Malt Barley
}

\author{
Hussien Sareta and Wogayehu Worku \\ Kulumsa Agricultural Research Center, Ethiopian Institute of Agricultural Research, \\ P.O.Box 489, Addis Ababa, Ethiopia
}

\begin{abstract}
A study was conducted at Bekoji and Kofele farmer's field in 2015/16 and 2016/17 cropping seasons to evaluate effectiveness of two post-emergence herbicides for the control of annual grass weeds in malt barley. Phenoxapropethyl 1 lit/ha, Fenoxaprop-p-ethyl $69 \mathrm{~g} / 1+$ safener-Mefenpyr-diethyl $75 \mathrm{~g} / 1 \mathrm{l}$ lit/ha, hand weeding twice (30-35 and 55-60 Days After Sowing) as a standard check and a weedy check, respectively were laid out in Randomized Block Design considering sites as a replications. Malt barley, Holker was used as a test variety. Annual grass weeds like Snowdenia polystachya, Avena fatua, Phalaris paradoxa and Setaria pumila were controlled by Phenoxapropethyl 1 lit/ha a.i and Fenoxaprop-p-ethyl 69 g/l + safener-Mefenpyr-diethyl 75 g/l a.i 1 lit/ha with an efficacy rate of 80 to $100 \%$. Fenoxaprop-p-ethyl69 g/l + safener-Mefenpyr-diethyl $75 \mathrm{~g} / 1$ had a yield advantage over Phenoxapropethyl and weedy check by 21 and 62\%, respectively. Application of Fenoxaprop-pethyl $69 \mathrm{~g} / 1$ + safener-Mefenpyr-diethyl $75 \mathrm{~g} / 1$ a.i (23027 Birr) had higher economic benefit than hand weeding twice (22158 Birr), Phenoxapropethyl a.i (17950 Birr) and weedy check (8670 Birr) by 4, 22 and 62\%, respectively. It was economically profitable with marginal rate of return of $2538 \%$ even if the price of herbicide is increased by $20 \%$ as proven by the sensitivity analysis. Hence, Fenoxaprop-p-ethyl $69 \mathrm{~g} / \mathrm{l}+$ safener-Mefenpyr-diethyl $75 \mathrm{~g} / \mathrm{l}$ a.i at a rate of 1 lit/ha as post-emergence application can be recommended for the control of annual grass weed species in Malt barley for agro-ecologies similar to the study areas.
\end{abstract}

Keywords: Fenoxaprop-p-ethyl 69 g/lit + safener-Mefenpyr-diethyl 75 g/lit, Grass weeds, Malt barley, Phenoxapropethyl, Post émergence herbicides

DOI: $10.7176 / \mathrm{JBAH} / 9-11-06$

Publication date:June $30^{\text {th }} 2019$

\section{INTRODUCTION}

Barley is the most commonly used grain in the production of malt for use in making beer of the world [1]. It is the fifth most important cereal crops after teff, maize, sorghum, and wheat, with yearly estimated harvests of about 1.9 million tons from over 1.02 million hectares of land with an average national yield of 1.85 tons per hectare [2]. The crop is predominantly grown from 2000 to 3500 meters above sea level in Ethiopia [3] and it is an important food grain and malting crop in the Ethiopian highlands, with malting barley a major source of income for smallholder farmers [4]. Malt barley is used for malting for various alcoholic beverages and food as bread, cultural dishes, biscuits, cakes and desserts. Brewers, distiller grains and sprouts from malting barley also have desirable protein content for animal diets [5].

Malt imports has grown tremendously reaching 63 thousand tons in 2015 covering $65 \%$ of total annual demand and costing the country about 37 million USD [6]. Although there is a considerable potential for increased production of high quality malting barley, the production of malting barley in Ethiopia has not expanded enough to benefit most barley growers. Among others, limited number of quality malt barley varieties and associated production technologies to farmers; biotic factors (mainly weeds, insect pests and foliar diseases), abiotic factors (low soil fertility, low soil $\mathrm{pH}$, poor soil drainage, drought and poor agronomic practices), weak technology transfer, poor access to markets and unattractive malt barley price are identified as the main constraints responsible for low productivity and limited expansion of malt barley [7].

The low national average yield which is far below the world average, could be partially attributed to poor weed management, which results in high competition from weeds. The crop is very sensitive to weed competition and suffer the greatest yield reduction through competition to its third to sixth leaf stage [8]. She also reported that the average yield loss in barley is about $18 \%$ when the crop has received no weed control and weeds caused a yield loss of $17-39 \%$ on barley in Ethiopia [9].

Grass weeds are becoming significant production constraints to barely in Ethiopia, due to the high proportion of cereal crops in the rotational systems in highlands and the repeated application of herbicides effective against broad leaf weeds. Among grass weeds, Avena fatua, Bromus pectinatus, Digitaria scalarum, Lolium temulentum, Phalaris paradoxa, Setaria spp. and Snowdenia polystachya are the most important and problematic weeds. There were no adequate grass weed killer herbicides used in malt barley so far in the study areas. Therefore, the objective of this study was to evaluate effective post-emergence herbicides for the control of annual grass weeds in malt barley. 


\section{MATERIALS AND METHODS}

\section{Description of the Study Areas}

The activity was conducted at Bekoji and Kofele farmer's field during the main cropping season of 2015/16 and 2016/17. Bekoji ( $7^{\circ} 32^{\prime} 37^{\prime \prime N}$ and 39 15'21" E, 2780 meters above sea level (masl), average rainfall of $1066 \mathrm{~mm}$, mean minimum and maximum temperature is $9.6^{\circ} \mathrm{C}$ and $24^{\circ} \mathrm{C}$, respectively, and soil texture of luvisol) found in Arsi zone. According to FAO, [10] Kofele $\left(07^{\circ} 05^{\prime} 0.2^{\prime \prime}\right.$ to $07^{\circ} 13^{\prime} 31.2^{\prime \prime} \mathrm{N}$ latitude and $038^{\circ} 47^{\prime} 06.8^{\prime \prime}$ to $038^{\circ} 56^{\prime} 54.6^{\prime \prime}$ E longitude, 2668 to 2682 masl, average rainfall of $1170 \mathrm{~mm}$, mean annual minimum and maximum temperature of $8.51^{\circ} \mathrm{C}$ and $19.63^{\circ} \mathrm{C}$, respectively, and soil texture of nitosol) found in West Arsi Zone. Bekoji and Kofele are situated $56 \mathrm{~km}$ and $170 \mathrm{~km}$ away from Assela town and $225 \mathrm{~km}$ and $240 \mathrm{~km}$ away in South west direction from Addis Ababa, respectively.

\section{Treatments and Experimental Design}

The treatments were Phenoxapropethyl at 1 lit/ha, Fenoxaprop-p-ethyl 69 g/l + safener-Mefenpyr-diethyl 75 g/l a.i at 1 lit/ha, hand weeding twice (30-35 and 55-60 days after sowing) as a standard check and a weedy check left as a control. A malt barley variety, Holker was used as a test variety. The trial was laid out in Randomized Complete Block Design (RCBD) using sites as a replication. Herbicides were applied post-emergence at 30-35 days after sowing (DAS). The seed was sown by broadcasting at a seeding rate of $100 \mathrm{~kg} / \mathrm{ha}$. At time of sowing, all plots received a basal application of $100 \mathrm{~kg} / \mathrm{ha}$ Diammonium Phosphate (DAP) and $50 \mathrm{~kg} / \mathrm{ha}$ Urea fertilizers in plot size of $10 \mathrm{~m}$ by $10 \mathrm{~m}$.

The required quantity of the herbicide was calculated and measured out into a manual knapsack sprayer with a water volume of $200 \mathrm{lit} / \mathrm{ha}$ for each herbicide treatment plots. Broad leaf weeds were controlled by using 2, 4-D herbicide at the rate of 1 lit/ha for herbicide treatments a week after the application of grass weed herbicides. All the necessary agronomic practices were done equally for all treatments.

\section{Data Collection}

Agronomic data: The necessary agronomic data of the crop (plant height, number of tillers per plant, spike length, thousand kernel weight (TKW), hectoliter weight (HLW), crop biomass and grain yield) and the weed (weed count before, two and four weeks after herbicide application using $1 \mathrm{~m}^{2}$ quadrat, weed biomass, general weed control score in 1-5 scale, (where 1= Complete eradication; $2=$ Effective destruction; $3=$ Proper reduction in growth and population; 4= Reduced growth and population and $5=$ no effect on weed control) were collected. The general weed control score was based on Rezene et al. [11]. Efficacy of herbicides was calculated using the following formula:

Weed count before herbicide application - Weed count after herbicde application

$$
\text { Weed count before herbicide application }
$$

Crop yield and yield components and weed biomass data was collected at time of harvest to supplement field observation.

Economic Analysis: Cost and benefit of each treatment was analyzed and marginal rate of return (MRR) was computed by considering the variable cost of each respective treatments. Yield and economic data were collected to compare the economic advantage of each herbicide in different treatments. Economic data included input cost that vary and costs for chemical and labour during the execution of the experiment. The price and cost items were expressed in Ethiopian Birr (ETB). The price of one liter Phenoxapropethyl and Fenoxaprop-p-ethyl 69 g/l + safener-Mefenpyr-diethyl $75 \mathrm{~g} / 1$ in 2016 was 600 and $800 \mathrm{ETB} /$ lit/ha, respectively. Costs of herbicides were obtained from pesticide companies and local distributing agencies. Labor cost for twice hand weeding was 2500 ETB/ha. Harvesting and threshing was done by manually using daily laborers which needed 20 and 30 man days with a daily laborer cost of $30 \mathrm{ETB} /$ day. Accordingly, the cost of harvesting and threshing of malt barley for Phenoxapropethyl, Fenoxaprop-p-ethyl $69 \mathrm{~g} / 1+$ safener-Mefenpyr-diethyl $75 \mathrm{~g} / 1$, twice hand weeding and a weedy check treatments using daily laborers was 1500, 1500, 1500 and $1050 \mathrm{ETB} /$ ha, respectively. Labor cost for three times plowing was uniform for each treatment and costs $2250 \mathrm{ETB} / \mathrm{ha}$. Cost for daily laborer and rent for knapsack sprayer for herbicide application was $110 \mathrm{ETB} /$ ha. Sale price of malt barley in 2016 was $800 \mathrm{ETB} /$ quintal. Cost for land preparation and inputs purchase (seed and fertilizers) were uniform for all treatments. The average yield was adjusted downward by $10 \%$, assuming that farmers could get $10 \%$ less yield than the experimental plot [12]. For determining gross returns, the prevailing local market price $800 \mathrm{ETB} / 100 \mathrm{~kg}$ of malt barley at the harvest of malt barley in 2016 was considered. Based on the data obtained from both locations, economic analysis was computed using partial budget analyses, marginal rate of return (MRR) and sensitivity analysis ( ${ }^{\mathrm{a}} \mathrm{MRR}$ ) even when herbicide cost was increased by $20 \%$ [12]. The following formulae were used to compute net field benefits (NBs) and marginal rate of return (MRR), respectively.

Net field benefits (NBs) $=$ Gross field benefits (GB) - Total Variable costs (TVC).

$\mathrm{MRR}=\frac{D N I}{D I C}$; where, MRR is the marginal rate of return; 
DNI is the difference in net income compared with control;

DIC is the difference in input cost compared with control.

\section{Data Analysis}

Data management and statistical analysis: Finally all yield and yield components data were subjected to analysis of variance using the general linear model procedure (Proc GLM) of SAS statistical package version 9.0 [13]. Mean separation was done using least significant difference test at the $5 \%$ level of probability.

\section{RESULTS AND DISCUSSION}

\section{Efficacy of Herbicides}

Efficacy result over locations indicated that all the treatments were effective against Snowdenia polystachya, Avena fatua, Phalaris paradoxa and Setaria pumila except Bromus pectinatus. Phenoxapropethyl, Fenoxaprop-pethyl69 g/l + safener-Mefenpyr-diethyl $75 \mathrm{~g} / \mathrm{l}$ and twice hand weeding controlled Avena species by 80, 96 and $100 \%$, respectively (Table 1). Likewise, Phenoxapropethyl, Fenoxaprop-p-ethyl $69 \mathrm{~g} / 1+$ safener-Mefenpyr-diethyl $75 \mathrm{~g} / \mathrm{l}$ and twice hand weeding controlled $S$. polystachya by $100 \%$, whereas $P$. paradoxa was controlled at efficacy rate of 83,100 and $100 \%$, respectively. Both herbicides controlled B. pectinatus less than 50\% efficacy rate, but twice hand weeding gave $90 \%$ control of B. pectinatus as shown in Table 1 . This result is in line with the report of Fasil [14] that the commercial product, Phenoxapro-p-ethyl and Dichlofopmethyl have been noted to give good control of Snowdenia polystachya, Echinochloa crus-galli, Bromus pectinatus, Avena fatua, Setaria species and Phalaris paradoxa with the exception of another species of Bromus. The reports of Belles et al. [15], and Michael and Mickelson [16] also proved that Tralkoxydim and fenoxaprop have been shown to control wild oat and other annual grassy weeds effectively in small grains with no effect on broadleaf weeds. Similarly, this result was in line with the works of Singh and Ali [17] who reported that the lowest weed control efficiency ( $0 \%)$ was observed under unweeded control because there is greater weed competition stress.

Table1. Efficacy (\%) of Fenoxaprop-p-ethyl $69 \mathrm{~g} / 1+$ safener-Mefenpyr-diethyl $75 \mathrm{~g} / \mathrm{l}$ as compared to Phenoxapropethyl on major grass weeds 4 weeks after application at two locations in Arsi and West Arsi Zones in 2016/17 cropping seasons

\begin{tabular}{|c|c|c|c|c|c|c|c|c|c|c|}
\hline \multirow[t]{2}{*}{ Locations } & \multirow[t]{2}{*}{ weed species } & \multicolumn{3}{|c|}{ Phenoxapropethyl } & \multicolumn{3}{|c|}{$\begin{array}{c}\text { Fenoxaprop-p-ethyl } 69 \mathrm{~g} / 1+\mathrm{safener}- \\
\text { Mefenpyr-diethyl } 75 \mathrm{~g} / 1\end{array}$} & \multicolumn{3}{|c|}{ Twice hand weeding } \\
\hline & & $\begin{array}{l}\text { Weed } \\
\text { count } / \mathrm{m}^{2} \\
\text { Before } \\
\text { Application }\end{array}$ & $\begin{array}{l}\text { Weed } \\
\text { count } / \mathrm{m}^{2} \\
\text { After } \\
\text { Application }\end{array}$ & $\begin{array}{l}\text { Efficacy } \\
(\%)\end{array}$ & $\begin{array}{l}\text { Weed } \\
\text { count } / \mathrm{m}^{2} \\
\text { Before } \\
\text { Application }\end{array}$ & $\begin{array}{l}\text { Weed } \\
\text { count } / \mathrm{m}^{2} \\
\text { After } \\
\text { Application }\end{array}$ & $\begin{array}{l}\text { Efficacy } \\
(\%)\end{array}$ & $\begin{array}{l}\text { Weed } \\
\text { count } / \mathrm{m}^{2} \\
\text { before } \quad 1^{\text {st }} \\
\text { hand } \\
\text { weeding }\end{array}$ & $\begin{array}{l}\text { Weed } \\
\text { count } / \mathrm{m}^{2} \\
\text { After } 15 \\
\text { Days of } \\
2^{\text {nd }} \text { hand } \\
\text { weeding }\end{array}$ & $\begin{array}{l}\text { Results } \\
(\%)\end{array}$ \\
\hline \multirow{4}{*}{ Bekoji } & $\begin{array}{l}\text { Snowdenia } \\
\text { polystachya }\end{array}$ & 6 & 0 & 100 & 8 & 0 & 100 & 0 & 0 & 0 \\
\hline & Avena fatua & 52 & 11 & 80 & 76 & 3 & 96 & 52 & 0 & 100 \\
\hline & $\begin{array}{l}\text { Bromus } \\
\text { pectinatus }\end{array}$ & 9 & 6 & 33 & 8 & 5 & 37.5 & 0 & 0 & 0 \\
\hline & $\begin{array}{l}\text { Phalaris } \\
\text { paradoxa }\end{array}$ & 18 & 3 & 83 & 27 & 0 & 100 & 15 & 0 & 100 \\
\hline \multirow[b]{4}{*}{ Kofele } & $\begin{array}{l}\text { Snowdenia } \\
\text { polystachya }\end{array}$ & 13 & 0 & 100 & 11 & 0 & 100 & 8 & 0 & 100 \\
\hline & Avena fatua & 0 & 0 & 0 & 5 & 0 & 100 & 0 & 0 & 0 \\
\hline & $\begin{array}{l}\text { Bromus } \\
\text { pectinatus }\end{array}$ & 5 & 3 & 40 & 0 & 0 & 0 & 6 & 0 & 100 \\
\hline & $\begin{array}{l}\text { Phalaris } \\
\text { paradoxa }\end{array}$ & 0 & 0 & 0 & 0 & 0 & 0 & 0 & 0 & 0 \\
\hline
\end{tabular}

\section{Yield and Yield Components}

The combined analysis over locations indicated that there was no significant difference between treatments on plant height, number of tillers/plant, spike length, thousand kernel weight (TKW) and hectoliter weight (HLW). On the other hand, grain yield showed significant $(P<0.05)$ difference due to Phenoxapropethyl, Fenoxaprop-pethyl $69 \mathrm{~g} / 1$ + safener-Mefenpyr-diethyl $75 \mathrm{~g} / 1$ and twice hand weeding (standard check) as shown in Table 2. Yield wise, Phenoxapropethyl, Fenoxaprop-p-ethyl 69 g/l + safener-Mefenpyr-diethyl 75 g/l and twice hand weeding outperformed in yield than the weedy check by 52, 62 and $63 \%$, respectively (Table 2). The highest grain yield $\left(3633 \mathrm{~kg} \mathrm{ha}^{-1}\right)$ was recorded in twice hand weeding followed by Fenoxaprop-p-ethyl $69 \mathrm{~g} / 1+$ safenerMefenpyr-diethyl $75 \mathrm{~g} / 1$ (3533 $\left.\mathrm{kg} \mathrm{ha}^{-1}\right)$ and Phenoxapropethyl $(2800 \mathrm{~kg} / \mathrm{ha})$. However, the lowest grain yield of $1350 \mathrm{~kg} \mathrm{ha}^{-1}$ was recorded in weedy check treatment. Similarly, Fenoxaprop-p-ethyl69 g/l + safener-Mefenpyrdiethyl $75 \mathrm{~g} / 1$ had a yield advantage over Phenoxapropethyl and weedy check by 21 and 62\%, respectively (Table 2). Yield loss due to weeds on barley was widely studied and explained in different countries. In the United States, wild oat density of 170 plants $\mathrm{m}^{-2}$ has been reported to reduce barley yield by $40 \%$ [18]. Similarly, in Australia, barley yield losses from 100 wild oat plants $\mathrm{m}^{-2}$ or more ranged from 30 to 50\% [19]. It has also been reported that competition from wild oat reduces worldwide bread wheat and barley production more than 12 million tons 
annually [20].

Dry weed biomass was significantly $(\mathrm{P}<0.05)$ different for applied treatments as shown in Table 2 . It was the lowest $\left(33 \mathrm{~kg} \mathrm{ha}^{-1}\right)$ in twice hand weeding followed by Fenoxaprop-p-ethyl $69 \mathrm{~g} / 1+$ safener-Mefenpyr-diethyl 75 $\mathrm{g} / 1\left(150 \mathrm{~kg} \mathrm{ha}^{-1}\right)$ and Phenoxapropethyl $\left(700 \mathrm{~kg} \mathrm{ha}^{-1}\right)$, while the highest $\left(1650 \mathrm{~kg} \mathrm{ha}^{-1}\right)$ was recorded in untreated weedy check treatment Table 2. These results are correlated with the study of Hossain et al. [21] who documented that application of post emergence herbicides reduced the weed dry weight and consequently increased weed control efficiency. These findings are also in agreement with the finding of Amare et al. [22] who reported that application of isoproturon @ 1.00kg a.i. ha ${ }^{-1}$ significantly reduced the weed dry biomass, which ultimately increased the weed control efficiency in wheat.

Table 2. Mean grain yield $\left(\mathrm{kg} \mathrm{ha}^{-1}\right)$ of Malt barley after Phenoxapropethyl and Fenoxaprop-p-ethyl $69 \mathrm{~g} / \mathrm{l}+$ safenerMefenpyr-diethyl $75 \mathrm{~g} / 1$ herbicides application at two locations in 2016/17 cropping seasons

\begin{tabular}{|c|c|c|c|c|c|c|c|c|c|c|c|}
\hline \multirow[t]{2}{*}{ No } & \multirow[t]{2}{*}{ Treatments } & \multirow{2}{*}{$\begin{array}{c}\text { Number } \\
\text { of } \\
\text { tillers }\end{array}$} & \multirow{2}{*}{$\begin{array}{l}\text { Plant } \\
\text { height } \\
(\mathrm{cm})\end{array}$} & \multirow{2}{*}{$\begin{array}{l}\text { Spike } \\
\text { length } \\
(\mathrm{cm})\end{array}$} & \multirow[t]{2}{*}{$\begin{array}{l}\text { TKW } \\
\text { (gms) }\end{array}$} & \multirow[t]{2}{*}{$\begin{array}{l}\text { Hectoliter } \\
\text { weight }\end{array}$} & \multirow{2}{*}{$\begin{array}{l}\text { Crop } \\
\text { biomass } \\
(\mathrm{kg} / \mathrm{ha})\end{array}$} & \multirow{2}{*}{$\begin{array}{l}\text { Grain } \\
\text { Yield } \\
(\mathrm{kg} / \mathrm{ha})\end{array}$} & \multirow{2}{*}{$\begin{array}{l}\text { Total Dry } \\
\text { weight of } \\
\text { weeds }(\mathrm{kg} / \mathrm{ha})\end{array}$} & \multicolumn{2}{|c|}{$\begin{array}{c}* * \text { GWCVS } \\
(1-5 \text { scale })\end{array}$} \\
\hline & & & & & & & & & & $2 * * *$ WAA & $\begin{array}{c}\text { At } \\
\text { Maturity }\end{array}$ \\
\hline 1 & Phenoxapropethyl & 5.2 & 104 & 6 & 46.70 & 61.4 & 6917 & $2800 \mathrm{~b}$ & $700 \mathrm{~b}$ & 2 & 3 \\
\hline 2 & $\begin{array}{l}\text { Fenoxaprop-p-ethyl } \\
69 \text { g/lit + safener- } \\
\text { Mefenpyr-diethyl } 75 \\
\text { g/lit }\end{array}$ & 4.4 & 103 & 6.4 & 46.90 & 61.8 & 9583 & $3533 a$ & $150 \mathrm{c}$ & 1 & 2 \\
\hline 3 & Two hand weeding & 4.0 & 101 & 6.2 & 48.10 & 63.6 & 7667 & $3633 a$ & $33 \mathrm{~d}$ & 1 & 2.5 \\
\hline 4 & Weedy check & 3.2 & 108 & 6.6 & 46.64 & 63.4 & 6333 & $1350 \mathrm{c}$ & $1650 \mathrm{a}$ & 4 & 4.5 \\
\hline & Mean & 4.2 & 104 & 6.3 & 47.08 & & & 2829 & 633 & & \\
\hline & $\mathrm{LSD}<0.05$ & & & & & & & 100 & & & \\
\hline & $\mathrm{CV} \%$ & & 4.45 & & 3.66 & & & 12.15 & & & \\
\hline
\end{tabular}

** General weed control visual score

***Weeks After herbicide Application

\section{Economic Analysis}

The results of partial budget analysis of the different treatments were presented in Table 3. Farmers earned the highest net field benefit of $23027 \mathrm{ETB} /$ ha from malt barley production through the application of Fenoxaprop-pethyl $69 \mathrm{~g} / 1+$ safener-Mefenpyr-diethyl $75 \mathrm{~g} / 1$ herbicide with an economic advantage over twice hand weeding (22157 ETB/ha), Phenoxapropethyl (17950 ETB/ha) and weedy check (8670 ETB/ha) by 4, 22 and 62\%, respectively. Moreover, the result of marginal rate of return (MRR) showed that Fenoxaprop-p-ethyl $69 \mathrm{~g} / \mathrm{l}+$ safener-Mefenpyr-diethyl $75 \mathrm{~g} / \mathrm{l}$ found to be profitable for farmers with a MRR of $2538 \%$. Similarly, the sensitivity analysis ( ${ }^{\mathrm{a}} \mathrm{MRR}$ ) result depicted that Fenoxaprop-p-ethyl $69 \mathrm{~g} / 1+$ safener-Mefenpyr-diethyl $75 \mathrm{~g} / \mathrm{l}$ remained the most profitable weed treatment even when the cost of herbicide is increased by $20 \%$ as shown in Table 4 . Demelash et al. [23] reported economical profitability with $844 \%$ MRR owing to integration of compost with mineral fertilizers in wheat production. Otinga et al. [24] also reported an increased net benefit of over 33\% in response to combined application of FYM and mineral fertilizer in maize production.

Table 3. Partial budget analyses for weed control with herbicides and two times hand weeding in 2016/17

\begin{tabular}{|l|l|l|l|l|}
\hline \multirow{2}{*}{$\begin{array}{l}\text { Adjusted mean yield and } \\
\text { different costs }\end{array}$} & $\begin{array}{l}\text { Treatments } \\
\text { Check }\end{array}$ & Phenoxapropethyl & $\begin{array}{l}\text { Fenoxaprop-p-ethyl 69 g/lit }+ \\
\text { safener-Mefenpyr-diethyl 75 } \\
\text { g/lit }\end{array}$ & $\begin{array}{l}\text { Two hand } \\
\text { weeding }\end{array}$ \\
\hline Adjusted mean yield (kg/ha) & 1215 & 2520 & 3179.7 & 3269.7 \\
\hline Gross field benefit & 9720 & 20160 & 25437 & 26157.6 \\
\hline Cost of herbicide (birr) & - & 600 & 800 & - \\
\hline $\begin{array}{l}\text { Herbicide application labor } \\
\text { cost \& rent of knapsack } \\
\text { (birr) }\end{array}$ & - & 110 & 110 & - \\
\hline $\begin{array}{l}\text { Labor cost for weeding } \\
\text { (birr) }\end{array}$ & - & - & - & 2500 \\
\hline Harvesting cost (birr) & 450 & 600 & 600 & 600 \\
\hline Threshing cost (birr) & 600 & 900 & 900 & 900 \\
\hline Total variable cost (birr) & 1050 & 2210 & 2410 & 4000 \\
\hline Net field benefit (birr) & 8670 & 17950 & 23027 & 22157 \\
\hline
\end{tabular}


Table 4. Marginal rate of return analysis for weed control with herbicides and two times hand weeding in 2016/17

\begin{tabular}{|l|l|l|l|l|l|}
\hline Treatments & $\begin{array}{l}\text { Rate } \\
\text { (lt/ha) }\end{array}$ & $\begin{array}{l}\text { Net field } \\
\text { benefit (birr) }\end{array}$ & $\begin{array}{l}\text { Total variable } \\
\text { costs (birr) }\end{array}$ & MRR $^{\text {MRR }^{\mathrm{a}}}$ \\
\hline Weedy check & - & 8670 & 1050 & & \\
\hline Phenoxapropethyl & 1.0 & 17950 & 2210 & 800 & 715 \\
\hline $\begin{array}{l}\text { Fenoxaprop-p-ethyl 69 g/lit + safener- } \\
\text { Mefenpyr-diethyl 75 g/lit }\end{array}$ & 1.0 & 23027 & 2410 & 2538 & 2098 \\
\hline Farmers' practice with 2 hand weeding & - & 22157 & 4000 & $\mathrm{D}$ & $\mathrm{D}$ \\
\hline
\end{tabular}

Note: ${ }^{a}$ MRR calculated for cost of herbicides increased by $20 \%$

D: treatments with $M R R<\mathbf{5 0} \%$ considered as dominated.

\section{CONCLUSION AND RECOMMENDATION}

Most of the grass weeds like Snowdenia polystachya, Avena fatua, Phalaris paradoxa and Setaria pumila were effectively controlled by Fenoxaprop-p-ethyl $69 \mathrm{~g} / 1+$ safener-Mefenpyr-diethyl $75 \mathrm{~g} / \mathrm{l}$. It has better weed control efficacy and yield advantage than Phenoxapropethyl herbicide. Moreover, this herbicide was found to be profitable for farmers with MRR of $2538 \%$. Besides, it was the most profitable weed treatment even if the cost of herbicide is increased by $20 \%$ as depicted by sensitivity analysis ( $\left.{ }^{\mathrm{a}} \mathrm{MRR}\right)$. Hence, the herbicide Fenoxaprop-p-ethyl $69 \mathrm{~g} / \mathrm{l}+$ safener-Mefenpyr-diethyl $75 \mathrm{~g} / 1$ a.i at a rate of 1 lit/ha post-emergence application can be recommended for the control of annual grass weeds in Malt barley for agro-ecologies similar to the study areas.

\section{ACKNOWLEDGEMENT}

The authors gratefully acknowledge Kulumsa Agricultural Research Center, Ethiopian Institute of Agricultural Research (EIAR), for supporting the financial requirements of the research work and Mr. Bedada Begna, Socioeconomics, extension and gender department of Kulumsa Agricultural Research Center is also acknowledged for preparing the economic analysis part of the research work.

\section{REFERENCES}

1. Anonymous (2013) Barley Network Progress Report 2012-13. All India Co-ordinated Wheat and Barley Improvement Project. DWR, Karnal, p-1.1

2. CSA (Central Statistical Agency) (2014) Agricultural sample survey 2013/2014 report on area and production of private peasant holdings in meher season, CSA, Addis Ababa, Ethiopia

3. Lakew, B., Gebre, H. and Alemayehu, F (1996) Barley production and research in Ethiopia. In: Gebre G, van Leur J, editors. Barley research in Ethiopia: past work and future prospects. Addis Ababa: IAR/ICARDA; p. $1-8$

4. Yirga, C., Alemayehu, F. and Sinebo, W (1998) Barley livestock production system in Ethiopia: an overview. In: Yirga C, Alemayehu F, Sinebo W, editors. Barley-based farming system in the Highlands of Ethiopia. Addis Ababa: EIAR; p. 1-10.

5. Emebiria, L., Moodya, D., Panozzoa, JF. and Read, J (2003) Mapping of QTL for malting quality attributes in barley based on a cross of parents with low grain protein.

6. Ethiopian Revenues and Customs Authority (ERCA) (2014) ERCA: http://www.erca.gov.et/index.jsp?id=aboutus

7. Bayeh M and Berhane L (2011) Barley research and development in Ethiopia - an overview. 1n Mulatu, B. and Grando, S. (eds). 2011. Barley Research and Development in Ethiopia. Proceedings of the 2nd National Barley Research and Development Review Workshop. 28-30 November 2006, HARC, Holetta, Ethiopia. ICARDA, PO Box 5466, Aleppo, Syria. pp xiv + 391

8. Stroud, A (1989) Weed Management in Ethiopia; An Extension and Training Manual. FAO, Rome, Italy.

9. Rezene Fessehaie (2005) Weed Science Research and Extension in Ethiopia: Challenges and Responses. Key note address. Ethiopian Weed Science Society $7^{\text {th }}$ Annual Conference. 24 -25 November 2005, EARO,Addis Ababa, Ethiopia.

10. Food and Agriculture Organization of the United Nations (FAO) (2005) Estimates of world production and harvested area. Data from FAOSTAT.fao.org.

11. Rezene Fessehaie, Natenael Wassie and Kedija Demsiss (2007) Effect of Propoxycarbozone-sodium and mesosulfuron-methyl for annual grass weed control in wheat. Ethiopian Journal of weed management, Volume 1, 2007 Ethiopian Weed Science Society EARO,Addis Ababa, Ethiopia. Pp. 53-61.

12. CIMMYT (International Maize and Wheat Improvement Centre) (1988) From agronomic data to farmer recommendation: an economics training manual completely revised edition. CIMMYT, Mexico. http://repository.cimmyt.org:8080/xmlui/bitstream/handle/10883/859/25152.pdf

13. SAS Institute (2002) SAS Institute Inc. Cary Google Scholar 
14. Fasil Reda (1996) Weed Control Research in Barely. In: Barely research in Ethiopia: Past work and future prospects. Proceedings of $1^{\text {st }}$ barley research review and strategy workshop held 16-19 October 1993, Addis Abeba, Ethiopia. Hailu Gebre and Joop Van Leur (edser ). PP. 100-103

15. Belles, DS., Thill, DC. and Shafii, B (2000) Rate and Avena fatua density effects on seed production and viability in Hordeum vulgare. Weed Sci. 48, 378-384.

16. Michael, G.P. and Mickelson, J.A (2001) Malt barley response to fenoxaprop-P alone and in tank mixtures. Proc. West. Soc. Weed Sci. 54:7.

17. Singh P and Ali M. 2004. Efficacy of metsulfuron-methyl on weedsin wheat and its residual effects on succeeding soybean crop grown on Vertisol of Rajasthan. Indian Journal of Weed Science 36(1\&2): 34-37.

18. Morishita, DW. and Thill, DC (1988) Factors of wild oat (Avena fatua) interference on spring barley (Hordeum vulgare) growth and yield. Weed Sci. 36:37-42.

19. Chancellor, RJ. and Peters, NCB (1976) Competition between wild oats and crops. In D.P. Jones, ed. Wild oats in World Agriculture. Agric. Res Coun. London. P. 99-112

20. Nalewaja, JD (1977) Wild oat: global gloom. Proc. West Soc. Weed Sci.30:21.

21. Hossain MI, Haque ME, Sayre KD, Gupta RK, Talukder SN and Islam MS et al. 2009. Herbicidal effect on the growth and yield of wheat. International Journal of Sustainable Crop Production; 4(5): 1-4.

22. Amare T, Sharma JJ and Zewdie K. 2014. Effect of weed control methods on weeds and wheat (Triticum aestivum L.) yield", World Journal of Agricultural Research; 2(3): 124-128. http://dx.doi.org/10.12691/wjar2-3-7

23. Demelash N, Bayu W, Tesfaye S, Zidat F, Sommer R (2014) Current and residual effects of compost and inorganic fertilizer on wheat and soil chemical properties. Nutr Cycling Agroecosyst 100(3):357367. https://doi.org/10.1007/s10705-014-9654-5 CrossRefGoogle Scholar

24. Otinga AN, Okalebo JR, Njoroge R, Emong'ole M, Six L, Vanlauwe B, Merckx R (2013) Partial substitution of phosphorus fertilizer by farmyard manure and its localized application increases agronomic efficiency and profitability of maize production. Field Crop Res 140:32-43. https://doi.org/10.1016/j.fcr.2012.10.003 CrossRefGoogle Scholar 